\title{
Correspondence
}

http://dx.doi.org/10.11646/phytotaxa.170.4.9

\section{Eugenia membranifolia: a long-forgotten Brazilian Atlantic rainforest Myrtaceae}

\author{
MARIANA DE OLIVEIRA BÜNGER ${ }^{1}$, FIORELLA FERNANDA MAZINE CAPELO ${ }^{2} \&$ JOÃO RENATO \\ STEHMANN ${ }^{1}$ \\ ${ }^{1}$ Laboratório de Sistemática Vegetal, Departamento de Botânica, Instituto de Ciências Biológicas, Universidade Federal de Minas \\ Gerais, CEP 31270-901, Belo Horizonte, MG, Brazil (maribunger@gmail.com) \\ ${ }^{2}$ Departamento de Ciências Ambientais, Universidade Federal de São Carlos - campus Sorocaba, João Leme dos Santos, Km 110 - SP- \\ 264, , CEP 18052-780, Sorocaba, SP, Brazil
}

\begin{abstract}
Eugenia membranifolia Niedenzu, a forgotten name in Brazilian Myrtaceae and presently known only from one isotype, is reported as the correct name for most of the gatherings until now identified as Eugenia bocainensis. We provide a detailed description of E. membranifolia with comments on its distribution, ecology and conservation status, and compare it with $E$. bocainensis.
\end{abstract}

Key words: Eugenia bocainensis, IUCN Red List, Myrteae, Phyllocalyx

\section{Introduction}

In the Brazilian Atlantic Forest, Myrtaceae is represented by c. 680 species, which comprise $10-15 \%$ of the total of trees by number of species, a higher percentage than any other family (Sobral et al. 2013). Particularly, Eugenia Linnaeus (1753: 470) is the richest genus in this biome (Oliveira-Filho \& Fontes 2000).

Along visits to herbaria and fieldworks for the preparation of a revision of the species of Eugenia sect. Phyllocalyx Niedenzu (1893), a section comprising about 26 species, of which several are frequent in the Brazilian Atlantic Forest, we spotted a problem concerning a frequently collected species presently identified as Eugenia bocainensis Mattos (1974:4) (Sobral 2011, Sobral et al. 2013). Based on the information presented below, we have concluded that all modern specimens assigned to this species indeed belong to Eugenia membranifolia Niedenzu (1893:92), presently known only from the type collection, and provide an expanded description of this species, with comments on distribution, ecology and conservation status.

Eugenia membranifolia Niedenzu, Natürl. Pflanzenfam. 3 (7):82. 1893.(Fig.1)

= Phyllocalyx membranaceus O. Berg, Fl. Bras. 14(1): 334. 1857. Type:-Brazil, "habitat ad urbem Rio de Janeiro", Gaudichaud 762 (holotype B f; isotype F!)

Shrubs or trees $1.5-10 \mathrm{~m}$. Blades elliptic, lanceolate or oblanceolate, coriaceous, 8-20 $\times 2.5-6.5 \mathrm{~cm}$, discolorous, glabrous; translucid glandular dots prominent and visible on both surfaces; apex acuminate; base obtuse or attenuate; midvein sulcate adaxially, raised abaxially; lateral veins 15 to 30 on each side, raised on both sides; marginal veins two, the first ca. $1 \mathrm{~mm}$ from the margin and a second vein 2-5 $\mathrm{mm}$ from the margin, the margin revolute; petiole 5-7 $\mathrm{mm}$ long, canaliculate, glabrous. Flowers solitary; pedicels terminal, rarely axillary, 3-13 mm long, glabrous, rarely puberulent; bracteoles ovate, 4-13 mm long, acute, glabrous or puberulent, frequently ciliate. Flower buds 5-13 mm long, when young ones with white trichomes covering the hypanthium; calyx lobes four, 5-15 mm long, glabrous, extending beyond the petals in bud. Fruits globose, to $5 \mathrm{~cm}$ in diameter, glabrous. Seeds one to four.

Specimens examined:-BRAZIL. Paraná: Guaraqueçaba, s/d, Hatschbach, G. 56137 (ICN, MBM). São Paulo:

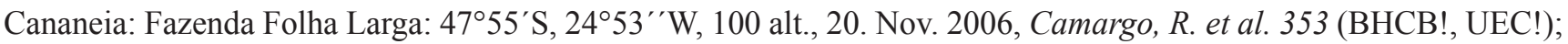

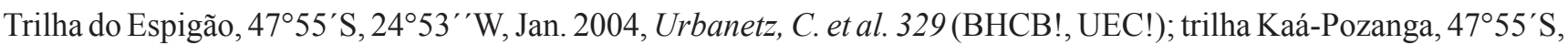




\section{References}

Berg, O. (1856) Revisio Myrtacearum Americae. Linnaea 27: 1-472.

Berg, O. (1857-1859) Myrtaceae. In: Martius, K.F.P. von (org.) Flora Brasiliensis 14(1): 1-656.

IUCN (World Conservation Union) (2013) IUCN Red List of threatened species. Available from www.iucnredlist.org (accessed May 2013).

Linnaeus, C. von (1753) Species Plantarum 1, Laurentius Salvius, Stockholm, 470 pp.

Mattos, J. R. (1975) Notas sobre Myrtaceae-II. Loefgrenia 64: 1-5.

Niedenzu, F. J. (1893) Myrtaceae. In: Engler, H.G.A. \& Prantl, K.A.E (eds.) Die Natürlichen Pflanzenfamilien. Leipzig, v 7, pp. 82.

Oliveira-Filho, A.T. \& Fontes, M.A.L. (2000) Patterns of floristic differentiation among Atlantic forests in southeastern Brazil and the influence of climate. Biotropica 32(4b): 793-810.

http://dx.doi.org/10.1111/j.1744-7429.2000.tb00619.x

Sobral, M. (2003) A família Myrtaceae no Rio Grande do Sul. UNISINOS. São Leopoldo, RS, Brasil.

Sobral, M., Proença, C., Souza, M., Mazine, F.F. \& Lucas, E. (2013) Myrtaceae in Lista de Espécies da Flora do Brasil. Jardim Botânico do Rio de Janeiro. Available from http://floradobrasil.jbrj.gov.br/2012 (accessed July 2013). 